\title{
Nigeria Versus Creditors: Who Really Owes Whom?
}

Richard O. Omotoye, (Email: romotye@vsu.edu), Virginia State University

\begin{abstract}
By current international standards, Nigeria is Africa's largest debtor, and indeed, one of the world's most debt-depressed. In view of that reputation and the stigma normally attached to it, the title of this paper- understandably so- might sound illusory, and may be even ridiculous to many. But even as unbelievable or fanciful as it might sound, there are solid, credible facts and figures that justify its relevance and validity. Conventionally speaking, Nigeria is by all means a huge debtor. In fact, its debt is so huge that hopes for repayment are beginning to fade. But viewed from a more comprehensive standpoint, facts and figures sharply contradict the overwhelming perception of indebtedness. The study, taking a more comprehensive approach, provides a reassessment of Nigeria's external debt amount, and compares its findings with creditors' figures. The findings are startling. In contrast to conventional wisdom, Nigeria is actually a net creditor vis-à-vis the rest of the world, with positive net credit ranging from estimates of $\$ 51.9$ billion to approximately $\$ 117.8$ billion. The paper concludes with findings that will further intensify the divide between the two sides of the debt debate: those in favor of forgiveness, and those against. The mere prospect of a possible obliteration of the detrimental stigma of indebtedness symbolizes a promise of new possibilities and hopes for Nigeria and other debt-depressed sub-Saharan African countries.
\end{abstract}

\section{INTRODUCTION}

\subsection{Justification}

$T$

his initiative does not represent an attempt to under-represent Nigeria's external debt problems. Neither should it be viewed as an attempt aimed at justifying debt forgiveness. Rather, it is a fact-finding, researchbased undertaking, aimed at investigating Nigeria's indebtedness.

It is important to revisit Nigeria's debt and that of entire sub-Saharan Africa for many reasons. First, given the limitedness of their resources, if sub-Saharan African countries will have any chances at all of catching up with countries of other regions, they simply can no longer afford to direct limited resources to non growth-supporting ventures, more so if such ventures are viewed questionable or seem to lack legitimate grounds.

Second, if a credible, mutually agreed resolution could be worked out, which both sides can realistically work towards, both creditors and debtors simply stand to benefit. As it is currently, while the divide between the two sides intensifies, the amount in dispute continues to mount and will soon reach levels that will not lend itself to resolution. Many think it has already reached that stage; and that for creditors to continue to expect any repayment in a near or any distant future is nothing but delusion. It seems that creditors would clearly stand better chances of being repaid by making endeavors to work with debtors in keeping the debt at levels that debtor countries can realistically work towards.

Third, the international creditor community is ethically and morally obligated to revisit the debt issue. If the sacrifice of domestic resources toward the repayment of a debt that many thinks lack legitimacy is already costing Nigeria some one-seventh of its annual export revenue (Omotoye, et. al., 2004) and the nation is still nowhere near a foreseeable resolution, then creditors can no longer be viewed as true partners in progress. And if in fact it can be proved that Nigeria actually owes less than the amount claimed by creditors, or better still, nothing at all (as will later 
be established in this paper), the international creditor community can be legally held accountable for intentionally blocking the country's path to economic stabilization.

\subsection{Reconciling Inconsistencies}

Since the perception by creditors and debtors of what constitutes a legitimate debt strongly differ, there is a critical need to clarify from the onset what exactly constitutes a legitimate debt and what is not. According to the World Bank, total external debt stock consists of public and publicly guaranteed long-term debt, private nonguaranteed long-term debt, the use of IMF credit, and short-term debt. The long-term component (consisting of public debt, publicly guaranteed debt, and private non-guaranteed debt) is defined as debt that has an original maturity of more than one year, owed to nonresidents and repayable in foreign currency, goods, or services. While the public debt component is an external obligation of the public sector, the publicly guaranteed component is an external obligation of a private debtor, which is guaranteed for repayment by the public sector, and the private non-guaranteed portion is an external obligation of a private debtor that is not guaranteed for repayment by a public entity. Historically, the principal share of Nigeria's external debt- in the range of 95 percent or more- is long-term debt, consisting almost entirely of public and publicly guaranteed debt.

Even as broadly representative as the World Bank classification of external debt might seem, it does not sufficiently underscore certain important characteristics necessary to accurately estimate sub-Saharan Africa's external debt. While it is helpful in classifying external debt by origination, it left out important details concerning the usage and benefit derived of originated debt. In view of the peculiarities surrounding external debt in sub-Saharan African countries, it is imperative to go beyond the generic, conventional approach in use within the international creditor community. Some of the circumstances peculiar to Nigeria and other sub-Saharan African countries justifying the need for a more elaborate, comprehensive treatment of external debt owed by them are mentioned below.

First, even though Nigeria's external loans primarily consists of officially originated public or publicly guaranteed debt, more often than not, the so-called target beneficiary- the Nigerian public- hardly ever get any appreciable benefit from their use. The funds, though officially originated, are largely diverted into private assets belonging to private individuals in government while the entire nation - usually without accruable benefits - is held ransom. Over the years, successive Nigerian administrations (both military and civilian) have indulged in this abominable practice. Second, while in most developed countries there is a comprehensible dividing line between the public sector and the private sector (more so in matters relating to records of international transactions), in most subSaharan African countries, this essential dividing line is either invisible or not existent at all. This makes it easy for officially originated public funds to disappear into private assets. Third, while most developed countries have a welldefined, transparent record of international transactions, there is a general lack of transparency in the financial records of international transactions and payments relating to many developing countries, especially those in sub-Saharan Africa. Very often, this is traceable to the willful desires by people in authority to manipulate or conceal official data.

The inconsistencies mentioned above have important implications for debt measurement. If officially acquired liabilities which are internationally recorded as public, national debt are being clandestinely hidden in some undercover private accounts (where they cannot be appropriately accounted for), a fundamental balance of payment identity principle is being violated and the two sides of debt equation will for ever be at variance. It is therefore crucial that debt measurement relating to a developing country like Nigeria be based on methodological procedures that take into account inherent financial irregularities.

In light of the peculiarities highlighted above and the need to appropriately make adjustments for them, this paper favors proposals by some authors [among them, Boyce and Ndikumana (2001)] suggesting the need to draw a technical line of distinction between the terms- "government" and "country". According to the proposal, a government is fundamentally different from a country. While a government is definable as an entity consisting of the leadership apparatus and persons who make up the governing body, a country comprises of the government and its citizenry.

Delineating a clear distinction between "country" and "government" is fundamentally important in view of its methodological and statistical implications for this study and for practice. 
To start with, in developed countries with well-developed, transparent record of transactions, where public sector records are clearly delineated from private sector transactions, the propensity and the urge for illegal diversion of resources is either not observable at all or at least kept to a minimum. Public and private debt estimation attempts therefore do not face above-mentioned obstacles.

But even more importantly, with respect to Nigeria and other countries where the incidence of public-sector financial irregularities is so pronounced, it is absolutely essential to trace the source of irregularity to its very root. The undeniable truth is that public resources (acquired either through external loans or other means) accumulated abroad in undercover private nests through power abuse by persons in government are nothing but public assets disguised as private assets. They are assets that rightfully and legitimately belong to the country, and for the purpose of methodological and statistical accuracy should be appropriately included in the country's external debt estimates. By not including them in the estimates, the suspect owners of the fictitious assets are being insulated from financial accountability. Following this line of reasoning, a sufficient ground is established for arguing that the national debt accounting for a developing country like Nigeria be done on a comprehensive basis to include not only estimates of public assets and publicly acquired liabilities recorded against it, but also estimates of overseas private assets (to the extent that reasonable grounds exist somehow linking the existence of such assets to publicly originated funds or resources).

\subsection{Evidence}

The line of thought suggesting the inclusion of Nigeria's foreign private assets as an inseparable component of the country's international debt estimates is founded on empirical evidence that is based on findings both from current research and past studies.

Attempt was made in current paper to investigate, independently, the existence of any historical linkage between private external assets and officially acquired external loans. Using capital flight as a proxy for measuring private external assets (capital flight estimation techniques are discussed in part two of paper), by way of simple OLS regression method, the study investigated evidence of historical linkage in trends between capital flight and external debt. In an effort to determine the most statistically appropriate variables for the analysis, the test was originally experimented with a multiple set of variables. Experimental dependent variables were total annual external debt stocks, per capita annual external debt stock, and annual change in external debt stocks. With respect to explanatory variables, the following were tested: estimates of cumulative capital flight with interest earnings (one calculated on a cumulative annual basis, and a second, measured as percentage of gross domestic product); and per capita cumulative capita flight with interest earnings. Others were estimates of capital flight adjusted for inflation (one calculated on a total basis, and another calculated as percentage of gross domestic product); and capital flight estimates adjusted for inflation and mis-invoicing. After observation of initial results from the preliminary variables, the panel was finally set up on the two most statistically significant- total annual external debt stock, representing the dependent variable; and cumulative capital flight with interest earnings (percentage of gross domestic product), representing the independent variable. The results of the investigation, ran on EVIEWS version 4.0, are reported in Table (5).

The results portray a strong evidence of historical linkage between external debt and overseas private assets. According to the results, between 1971 and 2002, cumulative capital flight with interest earnings calculated as percentage of gross domestic product accounted for 80 percent of the variation in external debt. Additional tests were also done to validate the robustness of the test results and coefficients. The results conclusively uncover evidence that officially borrowed external funds were routinely rerouted abroad.

The results did not contradict findings from past studies. In his 1997 study, Ajayi had observed that on a cumulative basis, capital flight is highest in countries with the largest amount of external debt- a trend that he referred to as the twin problems of heavy indebtedness and capital flight. According to him, among the severely indebted subSaharan African countries, the incidence recorded the highest prevalence in Nigeria, Sudan, Cote d'Ivoire, and Ethiopia. 


\subsection{Inclusive Versus Exclusive Debt Accounting}

The problem with the standard accounting practice favored by international creditors is that while international creditors (to their own advantage) make elaborate effort to inclusively record all of Nigeria's external liabilities, they take an exclusive approach to recording its assets. This inclusive recording of liabilities versus exclusive recording of assets leads to underreporting of huge overseas private assets and render conventional estimates of Nigeria's external debt grossly inaccurate. If recorded liabilities are being used to fund unrecorded assets, a fundamental balance of payment accounting principle is being violated, and debt records will forever be out of balance. The result is the huge contradictions in debt estimates by creditors and debtors; hence, inability to find resolution. Understandably, many African governments are not willing to assume past debts and are often quick to default on loans; doing so on grounds that creditors, time and again, choose to let the real debtors off the hook.

Recognizing these discrepancies, and in an attempt to reconcile them along the line of thought suggested above, an attempt is made in this study to reassess Nigeria's external debt; this time, on a comprehensive basis, by including estimates of overseas private assets into the country's external debt equation.

While an accurate estimate of private external assets is hard to come by, reliable estimates are not impossible. In section two, the paper provides an overview of methods of estimating private external assets, and makes use of the ones considered most appropriate for Nigeria's situation. Along the line of basic assets-liabilities accounting principle, computed estimates of private external assets (along with other recorded public assets) are added to recorded public liabilities to arrive at figures of net external debt.

The study uncovers evidence that Nigeria's private external assets, in fact, exceed its public external liabilities; meaning that Nigeria actually holds a net credit position vis-à-vis the rest of the world. The finding sharply contradicts the traditionally held perception of indebtedness and establishes a raison d'être for Nigeria to demand an alternative, altogether different framework in negotiating with its so-called "creditors" or (more appropriately) should we say "would-be debtors".

The study is organized into the remaining four sections that follow. Section two is an overview of methods for estimating private external assets and a review of past initiatives in the research area. Section three proposes an alternative methodology for estimating Nigeria's private external assets and external debt. The study's findings are discussed in section four. Section five concludes with an appraisal of the study's findings and discusses the possible implications for the future.

\section{ESTIMATING PRIVATE EXTERNAL ASSETS AND PAST STUDIES}

\subsection{Overview of Methods}

The traditional approach to estimating a developing country's private external assets is to estimate its capital flight. In general, the following capital flight methods can be distinguished in literature: (i) the Dooley method (ii) the hot money method (iii) the asset method (iv) the trade mis-invoicing method (v) the residual method. Each method is briefly described below.

\section{The Dooley Method}

Dooley (1986) perceives capital flight as the total amount of externally held assets of the private sector that do not generate income reported in the Balance of Payment Statistics (BOP) of a country. It computes total capital outflows as reported in the BOP, but suggests doing so with some modifications. It recognizes the difference between the change in the stock of external debt and the amount of external borrowing reported in the BOP statistics. If the former is larger than the latter, the difference is assumed to be part of capital flight. The difference between total capital outflows and the change in the stock of external assets corresponding to reported interest income is measured as capital flight. Capital flight, according to the Dooley method, is calculated as follows:

$\mathrm{TKO}=\mathrm{FB}+\mathrm{FI}-\mathrm{CAD}-\Delta \mathrm{FR}-\mathrm{EO}-\Delta \mathrm{WBIMF}$ 
where, TKO is total capital outflows; FB is foreign borrowing as reported in BOP statistics; FI is net foreign investment inflows; $\mathrm{CAD}$ is current account deficit; $\triangle \mathrm{FR}$ is the change in foreign reserves; $\mathrm{EO}$ is errors and omissions; $\triangle \mathrm{WBIMF}$ is the difference between the change in the stock of external debt reported by the World Bank and foreign borrowing reported in BOP statistics.

The stock of external assets corresponding to reported interest earnings is calculated as:

$\mathrm{ES}=\left(1+\mathrm{r}_{U S}\right) * \mathrm{INTEAR}$

where, ES is external assets; $\mathrm{r}_{U S}$ is the US deposit rate (assumed to represent international market interest rate);

INTEAR is reported interest earnings. Capital flight is then calculated as:

$\mathrm{KF}=\mathrm{TKO}-\mathrm{ES}$

\section{The Hot Money Method}

Based on the longstanding presumption that errors and omissions primarily arise due to inaccurate measurements of private short-term capital, this method, used by Cuddington (1986, 1987), proposes adding the errors and omissions item of BOP statistics to recorded short-term capital outflows, in order to get an estimate of total flows. It calculates capital flight as follows:

$\mathrm{KF}=\mathrm{SKO}+\mathrm{EO}$

where, SKO is total amount of short-term capital outflows; EO is errors and omissions.

The Asset (or Bank Deposit) Method

This method (Hermes and Lensink,1992) is especially instrumental in estimating the minimum amount of foreign bank deposits held by a country's citizens in foreign banks. Generally, due to the reasons listed below, bank deposit estimates tend to underreport actual amounts held overseas. First, some funds are held in bank deposits outside the major reporting centers; second, the nationality of account holders is not always known; third, substantial funds are held in assets other than bank deposits.

\section{The Trade Mis-Invoicing Method}

Empirical studies [(Ajayi, 1992), (Schneider, 2003)] portray that trade mis-invoicing (either in the form of under-invoicing of exports, or over-invoicing and under-invoicing of imports) have always been an important conduit of capital flight. Exporters under-invoice their export receipts in an effort to underreport foreign exchange earnings, and thereby build up foreign currency holdings overseas. Importers over-invoice in an attempt to receive more foreign exchange than they need. In a country with strict import regulation laws, importers also tend to have an incentive to under-invoice in an effort to circumvent import control laws, which limit import volumes to specific quota. However, due to the poor quality of export and import data needed for measuring trade mis-invoicing, many researchers (Ajayi, 1992) propose the use of this method only as a modification to the residual method (discussed below).

\section{The Residual Method}

This method measures capital flight by comparing the sources of capital inflows (net increases in external debt, and net inflow of foreign investment) with the uses of the inflows (current account deficit, and additions to foreign reserves).

According to past studies based on this method, data that is based on BOP (published annually by the International Monetary Fund (IMF)) do not accurately measure capital flight by this method. Generally, World Bank's data, available in Global Development Finance $(G D F)$, is considered to be a more reliable estimate of external debt 
flows, and is therefore, used instead. This can be explained by the following: First, inflows of external borrowing recorded in the BOP capital account are considerably smaller than the corresponding amount published in the GDF. Second, discrepancies between recorded inflows and outflows of foreign exchange in BOP are lumped together as "net errors and omissions" without clarification of statistical details. Third, the integrity of BOP current account data on export and import has always been undermined by widespread trade falsification practices, done by exporters and importers. The residual method is calculated as follows:

$\mathrm{KF}=(\Delta \mathrm{EDT}+\mathrm{DFI})-(\mathrm{CAD}+\Delta \mathrm{RES})$

where, KF is capital flight calculated by residual method; $\triangle \mathrm{EDT}$ is change in the stock of external debt; DFI is net foreign direct investment inflows; CAD is current account deficit; $\triangle \mathrm{RES}$ is net additions to the stock of official foreign reserves.

Acknowledging the difficulties of separating abnormal (or so-called illegal capital) from normal capital outflows, proponents of this method treat all types of capital flow as capital flight.

The residual method has often attracted the attention of many scholars of capital flight. Among them, World Bank researchers (1985), Erbe (1980), Claessens and Naude (1993), Zedilli (1987), and Pastor (1990). Other researchers have also used it with some modifications. They include Morgan Guaranty (1986), which added to the basis equation, change in short-term foreign assets of the domestic banking system.

\section{Drawbacks}

Each of the methods discussed above has its merits and drawbacks. The Dooley method draws a line of distinction between the so-called "normal capital outflow" and "abnormal" or "illegal outflow". Capital outflow motivated by the comparison of relative returns and risks at home and abroad is defined as a normal outflow; while an illegal outflow is considered to be motivated by the desire to hide assets from domestic authorities. However, the distinction does not appear to be very useful in a developing country context, because economic returns on domestic investment generally tend to exceed the rate of return to the source country on foreign assets (Lessard and Williamson, 1987). Two reasons are primarily responsible. First, a capital-short developing capital is further impoverished as a result of capital outflow, regardless of whether it occurs through the so-called normal or abnormal channels. Second, the rate of return on capital assets typically exceeds that on financial assets, since the local economy directly benefits from the opportunities created through a domestic investment- opportunities that include returns to domestic entrepreneurs, increased job opportunities and higher wages for domestic workers, cheaper products for consumers, additional income generated through taxes paid on interest and profits, and many more.

This paper, therefore, takes the position that capital flight should be recognized and treated as capital that left the country, which would otherwise have been available for investment in the domestic economy, regardless of the rationale behind the transfer. For a developing country where capital is already short in supply, drawing such a distinction is not really consequential. Either capital leaves the country as a result of desire by citizens to hide assets from authorities or it is motivated by a genuine desire to take advantage of perceived differential returns and risks between home and abroad, the domestic economy still suffers from the loss. Furthermore, in the Nigerian context, capital flight measurement that is based on hot money and bank deposit methods, which recognize for the most part, only short-term capital or financial assets in foreign bank accounts, will not be very useful. To begin with, capital outflow takes a variety of forms, and do not necessarily take the form of short-term capital or bank deposit. Furthermore, it is not a secret that the identity of financial assets belonging to affluent Nigerian citizens in overseas banks is generally hidden. Estimates of capital flight based on the hot money or bank deposit method will, therefore, grossly understate capital flight.

Regarding the trade mis-invoicing method, it was earlier in paper recognized that it could best serve as a supplementary tool. 
The current study finds the residual method (upgraded by the mis-invoicing technique) to be more useful for the purpose of an empirical investigation focusing on Nigeria. First, by not distinguishing between types of outflow, it provides a more comprehensive estimate of total outflow, and hence, a better chance for measuring the opportunity cost of capital that would otherwise have been available for domestic investment. Second, its modification by use of the trade mis-invoicing technique allows for adjustment that compensates for widespread trade over-invoicing and under-invoicing, which is characteristic of the Nigerian investment environment. Third, over time, the residual method (appropriately modified) has gradually gained a wider international acceptance in capital flight studies, including at the World Bank, and it has become much easier to obtain the data needed for its use.

\subsection{Past Studies}

Several studies have been done in the past on the related problems of capital flight and external debt. Some of them provide a good reference point for the current study. A brief review of the relevant ones is provided below.

Ajayi, in a 1997 study that investigated the magnitude of external debt and capital flight in sub-Saharan African countries, challenged the theoretical foundation and presumptions on which modern day debt resolution initiatives are based. His investigation, covering the 1980-1993 period, uncovered a binding linkage between what he termed a "debt-driven" and "debt-fueled" capital flight, on one hand, and a "flight-driven" and "flight-fueled" external borrowing, on the other hand. After experimenting with four different methods, he recommended the residual method (with modifications to it) as being the most appropriate for the circumstances of sub-Saharan African countries, given the need to interpret the study results in light of relevant economic aggregates and the reality of data deficiency facing researchers.

In their regional study focusing on sub-Saharan Africa's most severely indebted nations, Ndikumana and Boyce (2000) found that sub-Saharan African countries, categorized by the World Bank in the group of the world's most severely indebted low-income countries (SILICs) also suffered the most capital flight. Using the residual method (adjusted for trade mis-invoicing and fluctuation in the values of debt-denominated currencies), they discovered that between 1970 and 1996, total external assets in the countries (investigated as a group) exceeded external debts by a range of $\$ 14.5$ billion to $\$ 106.5$ billion, depending on the method used in correcting for the time value of private assets.

In an OECD working paper, Schneider (2003), further exploring the Kindleberger (1837) viewpoint, defined capital flight as that part of the outflow of resident capital which is motivated by economic and political uncertainty. In what he termed a broad definition of capital flight, he referred to all outflows of resident capital, which, if invested in the domestic economy, would yield a higher rate of social return. In analyzing recent regional trends in capital flight, Schneider observed that resident capital outflows are highest in Latin America and East Asia. According to him, region-wide resident capital outflow in sub-Saharan African is beginning to enter a period of slowdown; a trend he attributes to repatriation of resident capital.

In another study focusing on the determinants of capital flight in developing countries, Hermes, et al. (1997) investigated the relationship between capital flight and its key determinant variables. Using the Morgan Guaranty variation of the method as their base equation for measuring capital inflows and political risk, they used stepwise regression to investigate variables that appear to be most important in explaining capital flight. According to their study, policy variables and political instability are the primary determinants of capital flight in developing countries.

\section{Limitations}

The studies described above help to shed needed light on the problem of capital flight, portraying it as a common problem facing developing countries around the world. However, none of them adequately represent the purpose and need of the current study.

First, most of the investigations mentioned above are region-based studies, directed at the investigation of capital flight problems facing regions. At such, for the most part, they left out country-specific issues facing individual 
countries. Regrettably, empirical results that explain region-wide trends do not, necessarily, always account for country-level tendencies. For instance, if at all the declining trend of resident capital outflow, observed in Schneider, holds true for sub-Saharan Africa as a region, country-level empirical evidence based on Nigeria (section four of current work) shows the exact opposite. In further contradiction to Schneider, official sources, including World Bank and official Nigerian government data, so far, do not portray that Nigerian nationals with capital assets abroad are anywhere close to repatriating their assets.

Second, except for Boyes and Ndikumana and a few others, most of the studies on capital flight focused almost exclusively on the problems of measurement, scope, and investigation of the underlying determinants of capital flight. The current study is more concerned about investigating the status of indebtedness facing sub-Saharan African countries (based on Nigeria); and estimating the true debt amount actually owed external creditors. The investigation of capital flight done in study is based on the need to estimate overseas-based domestic private assets (which have to be added to estimates of public external liabilities) in order to be able to comprehensively estimate external debt amount.

Third, due to data quality problems and efforts being made to improve them, data from institutional establishments on which measurements are based get periodically revised. In doing so, data sets representing the same variable often fail to capture newer trends in the dynamics of the variable over time. In light of periodic revisions done to data sets and the declining empirical relevance of results of past studies based on them, over time, it becomes necessary to reinvestigate the same problem with the help of more recent data sets. In this respect, compared to previous works in the same research field, the current study, basing its investigation on newly revised data and recently observable trends, hold the promise of greater relevance.

\section{METHODOLOGY}

In line with the basic source-versus-needs methodology of the residual approach, financial inflows are compared with financial needs (equation 2.5). Financial inflows consist of annual increase in external debt (net external borrowing) and direct investment inflows (net direct investment inflows), while financial needs consist of current account deficit and net changes in official reserves.

\subsection{Adjustment for Trade Falsification}

Adjustment for capital lost through trade falsification (explained above) is done using trading partner estimate. The computation is done, based on data from the Direction of Trade Statistics Yearbook, published annually by the IMF. Under the assumption that trade data from developed countries are more accurate than corresponding official Nigerian data, recorded discrepancies provide evidence of mis-invoicing. To calculate total trade misinvoicing, estimates of export mis-invoicing are added to estimates of import mis-invoicing.

Export mis-invoicing with industrialized countries $\left(\mathrm{X}_{\mathrm{DIC}}\right)$ is calculated as follows:

$\mathrm{X}_{\mathrm{DIC}}=\mathrm{M}_{\mathrm{IC}}-\left(\mathrm{X}_{\mathrm{NG}} * \mathrm{CIF}\right)$

where, $\mathrm{M}_{\mathrm{IC}}$ is the value of industrialized countries' imports from Nigeria as reported by industrialized trading partners, $\mathrm{X}_{\mathrm{NG}}$ is Nigeria's exports to industrialized countries as reported by Nigeria, and CIF is the c.i.f./f.o.b. factor. Generally, imports are recorded c.i.f. (i.e. value of imports plus cost of freight and insurance), while exports are recorded f.o.b. (free on board). (The publication of the series for the c.i.f/f.o.b. factor in the Direction of Trade Statistics has been discontinued. Official computation is based on assumption of a factor of 1.10). A positive sign represents evidence of under-invoicing, and a negative sign is evidence of over-invoicing. Like most other developing countries, in the absence of any strong incentives for over-invoicing (in form of export incentive programs), it is expected that average $\mathrm{X}_{\mathrm{DIC}}$ for the investigation period will be a positive figure. 
Import discrepancy with industrialized countries $\left(\mathrm{M}_{\mathrm{DIC}}\right)$ is computed as follows:

$\mathrm{M}_{\mathrm{DIC}}=\mathrm{M}_{\mathrm{NG}}-\left(\mathrm{X}_{\mathrm{IC}} * \mathrm{CIF}\right)$

where, $\mathrm{M}_{\mathrm{NG}}$ is Nigeria's imports to from industrialized nations as reported by Nigeria, and $\mathrm{X}_{\mathrm{IC}}$ is industrialized countries exports to Nigeria as reported by the industrialized countries. A negative sign on $\mathbf{M}_{\text {DIC }}$ is evidence of overinvoicing, while a negative sign represents under-invoicing.

To obtain total export mis-invoicing ( $\mathrm{X}_{\mathrm{MISINV}}$ ), the computed figure of export discrepancy with industrialized countries $\left(\mathrm{X}_{\mathrm{DIC}}\right)$ is multiplied by the inverse of the average share of industrialized countries in Nigeria's export $\left(1 / \mathrm{ICX}_{\mathrm{NG}}\right)$. Total import mis-invoicing ( $\left.\mathrm{M}_{\mathrm{MISINV}}\right)$ is obtained by multiplying the value of import discrepancy with industrialized countries $\left(\mathrm{M}_{\mathrm{DIC}}\right)$ by the inverse of the average share of industrialized countries in Nigeria's import $\left(1 / \mathrm{ICM}_{\mathrm{NG}}\right)$.

$\mathrm{X}_{\mathrm{MISINV}}=\mathrm{X}_{\mathrm{DIC}} *\left(1 / \mathrm{ICX}_{\mathrm{NG}}\right)$

$\mathrm{M}_{\mathrm{MISINV}}=\mathrm{M}_{\mathrm{DIC}} *\left(1 / \mathrm{ICM}_{\mathrm{NG}}\right)$

Total trade mis-invoicing (TRDMISINV) is then computed as a sum of export mis-invoicing ( $\mathrm{X}_{\text {MISINV}}$ ) and import mis-invoicing $\left(\mathrm{M}_{\mathrm{MISINV}}\right)$ :

TRDMISINV $=\mathrm{X}_{\text {MISINV }}+\mathrm{M}_{\text {MISINV }}$

Adding trade mis-invoicing to the initial estimates of capital flight from equation (2.5) yields estimates of capital flight adjusted for trade mis-invoicing $\left(\mathrm{KF}_{\mathrm{TRDMISINV}}\right)$.

$\mathrm{KF}_{\mathrm{TRDMISINV}}=\mathrm{KF}+\mathrm{TRDMISINV}$

\subsection{Adjustment for Inflation}

Adjustment for inflation makes it possible to meaningfully compare annual capital flight estimates spanning the investigation period, and help underscore the relevance of relationships between capital flight and other economic aggregates. The US producer price index is used as a proxy for inflation. Real capital flight, adjusted for trade falsification $\left(\mathrm{RKF}_{\mathrm{TRDMISINV}}\right)$, is calculated as follows:

$\mathrm{RKF}_{\mathrm{TRDMISINV}}=\mathrm{KF}_{\mathrm{TRDMISINV}} / \mathrm{PPI}_{\mathrm{US}}$

where, $\mathrm{PPI}_{\mathrm{US}}$ is the US producer price index calculated in constant 1995 dollar.

\subsection{Adjustment for Interest Earnings}

An alternative way to estimate the time value of private assets that fled Nigeria is to estimate the opportunity cost of interest earnings that the assets would have earned (over the years in flight) had they been domestically invested. Given that it is not possible to estimate the portion that would have been spent on consumption, the computations in study are done based on the assumption that the entire amount would have been invested at an assumed market interest rate. The US Treasury Bill rate is used as a proxy for international interest rate. The stock of

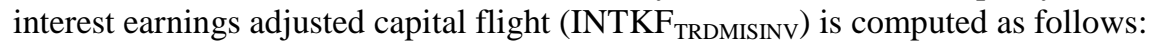

$\mathrm{INTKF}_{\text {TRDMISINVt }}=\operatorname{INTKF}_{\text {TRDMISINVt-1 }}(1+\mathrm{TBILL})+\mathrm{KF}_{\text {TRDMISINV }}$

where, TBILL is the interest rate on three-month U.S. treasury bills. 


\subsection{Net External Assets}

Finally, figures representing Nigeria's net private external assets vis-à-vis the rest of the world are computed. Net private external asset is computed as the difference between private external assets and public external liabilities. Two estimates of net external assets are computed, one based on capital flight estimates adjusted for inflation, and the other, based on capital flight estimates adjusted for interest earnings. When estimates of private external assets are positive, it means that Nigeria is a net creditor vis-à-vis the rest of the world, and when the figures are negative, it means that the country is a net debtor in corresponding years.

Arguing that debt data on which the computations are based is reported by the World Bank in a common currency (i.e. the U.S. dollar) even though countries denominate their foreign debts in different currencies, some authors- among them, Boyce and Ndikumana (2002)- suggested correcting for fluctuation in the value of the dollar against other currencies. They argued that during years of significant fluctuations in the value of the currencies in which those debts are denominated, year-to-year changes in the dollar value of outstanding debt could significantly vary from actual net flows.

In the current one-country investigation focusing exclusively on Nigeria, results from preliminary computations done revealed that fluctuation in currency valuation did not significantly affect capital flight estimates. This statistical insignificance could probably be explained by the following reasons.

First, official records show that a large portion of Nigeria's long-term debt is denominated in unspecified currencies that are simply lumped together and referred to as "multiple currencies" and "all other currencies" (see Table 1). Inasmuch as these currencies are not specified, it is impossible to track their relative fluctuations against the dollar, let alone against each other. Understandably, past studies aimed at adjusting for currency fluctuation, for the most part, have left out this portion. This untrackable portion is a relatively high percentage of Nigeria's total debt composition- 28 percent on average (see Table 1). Such a high percentage out of total debt composition underscores the needlessness of currency adjustment.

Second, as can be observed from Table (1), an increasing proportion of Nigeria's external debt is being denominated in the U.S. dollar. Probably, this is being done in an effort to minimize valuation difficulties associated with dollar fluctuation as noted above. The undenominated portion (mentioned earlier) added to the percentage composition denominated in the U.S. dollar constitutes a very high proportion of Nigeria's total long-term debt- a 68 percent average for the period (see Table 1). This leaves behind only 32 percentage of total long-term debt for fluctuation adjustment. This further rationalizes the statistical insignificance of the preliminary currency adjustment done in study; hence the needlessness of adjustment.

Third, the study's preliminary result uncovering statistical insignificance is supported by past findings. Cumby and Levich [in Lessard and Williamson (1987), page 44], in their study, which investigated Latin American countries that suffered from capital flight, similarly observed that except a very large fraction of a country's external debt is denominated in currencies other than the U.S. dollar, generally, exchange rate fluctuation would not result in substantial underestimates or overestimates of capital flight.

\section{FINDINGS}

In broad terms, the results of the investigation are comparable with results from past studies that are based on similar methodology. However, in light of certain extreme circumstances surrounding the investigation (explained below), which unfortunately are beyond the control of the researcher, sometimes, the results cannot be interpreted literally; they can only be interpreted in the context of the need and purpose at hand.

First, the official data on which computations are based is revised periodically. It is therefore not unusual to observe some divergence in data sets and results representing same variables when compared with other studies. Second, due to compilation problems, official data represent only approximate estimates of correct data when the latter is absent. For example, the computation of trade mis-invoicing done by way of estimating trading partners' 
figures do not leave much room for calculating and knowing actual discrepancy in trade volumes between trading partners. Thus for the five years between 1998 and 2002, computed trade mis-invoicing (after applying the cif/fob correction factor) was zero; this does not necessarily translate into the absence of over-invoicing or under-invoicing during those years. It is simply the result of a computation, based on trading partners' estimates.

The initial estimates of capital flight (computed without adjustment for mis-invoicing) are represented in Table (2). It shows a cumulative estimate of $\$ 66.2$ billion (in 1995 dollars) in Nigeria's private assets in various overseas investment vehicles over the 32-year period of investigation. Calculated on a per-annum basis, the estimates are equal to $\$ 2.1$ billion.

The study uncovers evidence of under-invoicing, showing that Nigerian exporters understate their true earnings in order to retain foreign currency abroad. At the import side, under-invoicing seems to outweigh overinvoicing, probably due to persistent smuggling. Adjusting for mis-invoicing did not significantly change the initial estimate of capital flight. This might be due to extreme variations in data. Generally, due to the poor quality of trade data, computed estimates of mis-invoicing ought to be interpreted with extreme caution.

Estimates of capital flight adjusted for trade mis-invoicing are presented in Table (3). One represents estimates adjusted for inflation; the other- estimates calculated with imputed interest earnings, representing the opportunity cost of capital. For the entire period, real capital flight (i.e. inflation-adjusted) was equal to $\$ 82.4$ billion or an average annual rate of approximately $\$ 2.6$ billion. Expectedly, estimates of cumulative capital flight with imputed earnings are higher, showing positive interest rate during the period of investigation. Cumulative estimate for the entire period is $\$ 148$ billion, or $\$ 4.6$ billion on an annual average basis.

Relative to 1992 gross domestic product (GDP), average annual capital flight adjusted for inflation is 10.7 percentage. Cumulative capital flight (adjusted for interest earnings) relative to 1992 GDP is 450 percent. Measured on a per capita basis, cumulative capital flight with interest earnings was $\$ 1,116$ (using 2002 population data), at a time when per capita GDP was $\$ 248$ for the same year and \$267 annual average for the period. On the average, cumulative stock of capital flight, on per capital basis, is more than four times greater than average per capital GDP. A 4 to 1 ratio per head capital flight and per head GDP is not only pathetic, but also unsustainable for the future of a nation that is known to be historically deficient in capital.

The highlight of the study is Table (4) where estimates of net private external assets are presented. Net external asset is calculated as the difference between capital flight (representing private external assets) and external debt stock (representing public liabilities). Two estimates are presented, each based on the corresponding method used in estimating capital flight. When computed difference is positive, it means that Nigeria has credit vis-à-vis the rest of the world; when negative, it is evidence of indebtedness.

The results sharply contradict the traditional perception of indebtedness that has haunted Nigeria for so long. Calculated from inflation-adjusted capital flight estimates, Nigeria is a net creditor with a positive net credit of $\$ 51.9$ billion. Computed from interest earnings capita flight estimates, the country becomes an even larger net creditor, with a credit in the amount of $\$ 117.8$ billion! Calculated by the interest earnings measurements, net external assets amount to $\$ 887$ per capita- a figure that is more than three times the annual average per capita GDP. Its ratio to 2002 GDP is 357 percent!!

It is very reassuring to observe that the study's results are comparable with similar investigations that were based on the same methodology. In their study, Boyes and Ndikumana (1987) reported net external assets ranging from $\$ 55$ billion (adjusted for inflation) to $\$ 98$ billion (with adjustment for interest earnings) for Nigeria for the 19701996 period. Giving the fact that sixteen of the countries in their study have negative net external credits vis-à-vis the rest of the world (compared to nine that have positive net balance), their estimate of total net private external assets for the region as whole was lower, when compared to Nigeria. It ranged from $\$ 14.5$ billion, when calculated by the inflation-adjusted method, to $\$ 106.5$ billion when calculated by interest earnings. According to their investigation, apart from being sub-Saharan Africa's leading creditor, the ratio of Nigeria's net external private credit to that of subSaharan Africa as a whole ranges from 0.92 (when the calculations are based on the interest earnings method) to 3.8 
(when computed from inflation-adjusted method). The evidence reveals that Nigeria suffered the most capital flight in sub-Saharan Africa; hence, it has the largest credit balance vis-à-vis the rest of the world.

The findings of the current study strongly contradict the widely held perception that Nigeria is sub-Saharan Africa's largest debtor country, and one of the world's most indebted. With so much in private assets hidden in various overseas investment vehicles, Nigeria should probably be referred to as one of the world's largest creditor nations.

\section{CONCLUSION AND FORWARD-LOOKING ISSUES}

The findings presented above symbolize a sharp divergence from the traditional perception (or should I say "myth") of indebtedness that has haunted Nigeria and perhaps the whole of sub-Saharan Africa for so long. If the evidence is so compelling that Nigeria's external assets far exceed her external liabilities, then her classification and continuing treatment by the international creditor community as a debtor nation (which compel her to pay more than a billion dollars in annual debt service obligations to creditors) should be open to debate.

The recognition that a questionable, "phantom" debt is costing Nigeria so much in resources (almost 1.5 billion dollars annually!) strongly weakens the sincerity and genuineness of gestures behind the various debt relief packages proposed by international monetary establishments, and casts serious doubt on the credibility of existing framework on which modern-day debt resolution initiatives are based. Moreover, it would lead any fair-minded to ask what can be considered an ethical, reasonably justified question: Who really owes whom?

The findings of the study, without intending to do so, might also become instrumental in further polarizing the divide between the two sides of the debt debate: those in favor of debt reduction/cancellation and those against. Arguing from the standpoint of moral hazard theory (Joseph P. Daniels, David VanHoose, 2002), which claim that indebted nations cannot be shielded from their debt obligations because of the wrongful perception of insulation offered debtors, opponents of debt forgiveness lament that debt forgiveness will mean bad business for the credit market and will discourage investors from investing in debt. While the validity of the claim may seem undeniable, this paper at the same time takes the position that the same principle should apply both ways. If creditors choose to look the other direction when public officers divert national wealth into private assets, are they not deliberately encouraging future stealing of public money; and should they not share in the risk of loss if a new government refuses to be held accountable for past loans? This moral hazard principle especially looses legitimacy when (according to Jubilee Plus) approximately 40 percent of Nigeria's outstanding principal is the result of loans contracted to military officers; not without creditors knowing fully well that the funds would be diverted into private assets (New Economics Foundation, 2001).

Increasingly, the viewpoint challenging Nigeria's external debt- and indeed entire sub-Saharan Africa's- is beginning to attract the attention of scholars, policy makers, and increasingly also, popular media [(Financial Times, 2000; New York Times, 2002)]. In light of mounting evidence weighing in its favor, in recent times, it has provoked official investigations in some countries, including Great Britain (The United Kingdom Parliament, May 2003), and congressional hearings at the United States (U.S. House of Representatives, May, 2000). The increasing attention has either helped to uncover the trails of hidden accounts in western banks or led to the recovery of some funds. According to Jubilee Plus, (2001), by June 2000, $\$ 450$ million of Nigerian looted funds had been recovered, while $\$ 1.2$ billion was frozen in banks in Switzerland and Luxemburg, pending further court action.

The findings presented above provoke the following conclusive remarks:

1. By not addressing the circumstances behind the origination and accumulation of Nigeria's external debt, the current resolution framework favored by the international creditor community is not solution-oriented. In order to achieve a complete breakthrough, an alternative, more comprehensive framework that truly reflects the debt origination circumstances will have to be developed.

2. Evidences increasingly portray that severely indebted African countries are falling behind in their debt obligations, not just because they are financially handicapped, but essentially because of what they perceive 
as illegitimately acquired debt being forced upon them. Given their belief that the parties that are actually responsible are being let loose, they are not motivated to settle.

3. It makes sense for both sides to work together in developing realistic proposals that they can both work towards. In the absence of a mutually agreed goal, the debts are beginning to approach sizes that debtors will not be able to repay. Neither creditors nor debtors will benefit from a permanent debt divide.

4. By looking the other direction when fraudulent individuals and authorities from developing countries steal public money, regulators in developed countries are abetting larceny and unscrupulously assisting the illegal transfer of illegitimate wealth to the west; obviously to their own advantage! If authorities in developed nations would honestly like to help curb this ugly predisposition, they can- through effective legislation, increased monitoring and enforcement- do a lot more to assist developing countries that are willing to work with them. For instance, in the United States, there are already federal laws that oblige banks to report to the Federal Reserve System transfers (from any single account) of more than $\$ 9,999$. The same laws could be extended to monitor fund transfers from developing countries.

5. Provoked by the September 2001 terrorist attacks, authorities in the west have put in place legislation that empower them to probe and freeze suspect assets traceable to international terrorists. Judging by their actions and the suffering that their shameful actions have subjected the citizens of their countries to, public officials and individuals from developing countries who steal money and launder them in undercover western investment vehicles should not be treated any different from terrorists! All suspect assets (both financial and non-financial), traceable to them should be appropriately probed, frozen, and (through a legitimate government) returned back to the rightful owners- i.e. the public. If there is no legitimate government in power, the assets should be permanently frozen until there is one.

\begin{tabular}{|c|c|c|c|c|c|c|c|c|c|c|c|c|c|}
\hline Currency & $\begin{array}{l}\text { Percent. } \\
\text { comp. }\end{array}$ & 1971 & 1975 & 1980 & 1981 & 1985 & 1990 & 1991 & 1995 & 1999 & 2000 & 2001 & 2002 \\
\hline U.S. dollars & 40.1 & 14.8 & 11.4 & 55 & 53.4 & 48.8 & 38.8 & 35.5 & 29.6 & 32.3 & 85.1 & 86.6 & 86.2 \\
\hline Swiss franc & 0.6 & 0.2 & 0 & 0.4 & 2.2 & 1.4 & 0.7 & 0.7 & 0.6 & 0.5 & 0 & 0 & 0.1 \\
\hline SDR & 0.0 & 0 & 0 & 0 & 0 & 0 & 0 & 0 & 0 & 0.2 & 0.1 & 0.1 & 0.1 \\
\hline Pound sterling & 9.6 & 26.8 & 11.5 & 2.7 & 1.6 & 7.9 & 11.8 & 12.3 & 9.9 & 12.8 & 1.5 & 1.5 & 1.3 \\
\hline All other currencies & 7.2 & 10.4 & 9.3 & 3.4 & 4.3 & 4.4 & 6.3 & 6.9 & 10.7 & 10.3 & 3.9 & 3.3 & 3.4 \\
\hline French franc & 5.2 & 0.2 & 0.5 & 0.9 & 2.2 & 5.8 & 9 & 10.4 & 10.9 & 9.5 & 1 & 0 & 0 \\
\hline Deutsche mark & 11.1 & 6.7 & 5.7 & 23.5 & 25 & 13.1 & 14.8 & 14.6 & 14.2 & 10.1 & 0.7 & 0 & 0 \\
\hline Multiple currencies & 19.6 & 38.6 & 57.6 & 12.1 & 10 & 11.1 & 10.4 & 10.2 & 11.5 & 9 & 5.4 & 4.6 & 4.6 \\
\hline Euro & 0.1 & 0 & 0 & 0 & 0 & 0 & 0 & 0 & 0 & 0 & 0 & 1.9 & 2.2 \\
\hline \multirow[t]{2}{*}{ Japanese yen } & 6.5 & 2.3 & 4 & 2 & 1.3 & 7.5 & 8.2 & 9.4 & 12.6 & 15.3 & 2.3 & 2 & 2.1 \\
\hline & 100.0 & 100 & 100 & 100 & 100 & 100 & 100 & 100 & 100 & 100 & 100 & 100 & 100 \\
\hline $\begin{array}{l}\text { Proportion of total: } \\
\text { Multiple and all other } \\
\text { currencies }\end{array}$ & 26.8375 & 49 & 66.9 & 15.5 & 14.3 & 15.5 & 16.7 & 17.1 & 22.2 & 19.3 & 9.3 & 7.9 & 8 \\
\hline \begin{tabular}{|l|} 
Multiple, all other \\
currencies, And US \\
dollars
\end{tabular} & 66.8937 & 63.8 & 78.3 & 70.5 & 67.7 & 64.3 & 55.5 & 52.6 & 51.8 & 51.6 & 94.4 & 94.5 & 94.2 \\
\hline
\end{tabular}


Table 2: Capital Flight Without Adjustment For Trade Misinvoicing (1971-2002)

\begin{tabular}{|c|c|}
\hline \multicolumn{2}{|c|}{ (Millions of US Dollars) } \\
\hline Years & Capital Flight without adjustment for trade mis-invoicing \\
\hline 1971 & 618.14 \\
\hline 1975 & 181.22 \\
\hline 1980 & $11,855.62$ \\
\hline 1981 & $(9,903.66)$ \\
\hline 1985 & $4,179.72$ \\
\hline 1990 & $10,980.76$ \\
\hline 1991 & $2,552.49$ \\
\hline 1995 & $(438.94)$ \\
\hline 1996 & $5,034.75$ \\
\hline 1997 & $2,591.11$ \\
\hline 1998 & $(1,835.34)$ \\
\hline 1999 & $(1,305.23)$ \\
\hline 2000 & $16,751.18$ \\
\hline 2001 & $7,086.47$ \\
\hline 2002 & $(1,363.35)$ \\
\hline Total & $66,179.91$ \\
\hline \begin{tabular}{|c} 
Annual Average \\
\end{tabular} & $2,068.12$ \\
\hline $\begin{array}{l}\text { Sources: Results from author's computations based on data } \\
\text { from the following databases: }\end{array}$ & \\
\hline $\begin{array}{l}\text { 1. IMF, Direction of Trade Statistics Yearbook (on-line } \\
\text { version). }\end{array}$ & \\
\hline 2. IMF, Global Development Finance, 2003 (on-line version). & \\
\hline 3. IMF, International Financial Statistics (on-line version). & \\
\hline $\begin{array}{l}\text { 4. World Bank, World Development Indicators, } 2003 \text { (on-line } \\
\text { version). }\end{array}$ & \\
\hline
\end{tabular}




\begin{tabular}{|c|c|c|c|c|c|c|}
\hline \multicolumn{7}{|c|}{$\begin{array}{l}\text { Table 3: Capital Flight Estimates (1971 - 2002) } \\
\text { (Millions of US Dollars) }\end{array}$} \\
\hline \multirow[t]{2}{*}{ Year } & \multicolumn{2}{|c|}{\begin{tabular}{|c|}
$\begin{array}{c}\text { Cumulative Capital Flight } \\
\text { with Interest Earnings }\end{array}$ \\
\end{tabular}} & \multirow[t]{2}{*}{\begin{tabular}{|l} 
Per Capita cum. cap. \\
Flight with int. earnings
\end{tabular}} & \multirow{2}{*}{$\begin{array}{l}\text { Capital Flight Adjusted for } \\
\text { Inflation Total (1995 US\$) }\end{array}$} & \multirow[t]{2}{*}{$\%$ of GDP } & \multirow{2}{*}{$\begin{array}{l}\text { GDP Per } \\
\text { Per Capita }\end{array}$} \\
\hline & Cum. Total & $\%$ of GDP & & & & \\
\hline 1971 & 618.14 & 3.85 & 11.30 & $2,024.38$ & 12.59 & 293.83 \\
\hline 1975 & $8,795.88$ & 47.68 & 143.63 & 387.06 & 2.10 & 301.21 \\
\hline 1980 & $26,933.55$ & 120.47 & 378.56 & $16,470.01$ & 73.67 & 314.24 \\
\hline 1981 & $20,158.22$ & 103.79 & 274.60 & $(12,607.06)$ & $(64.91)$ & 264.58 \\
\hline 1985 & $25,354.21$ & 132.32 & 304.75 & $5,055.31$ & 26.38 & 230.32 \\
\hline 1990 & $64,902.44$ & 261.03 & 674.64 & $11,785.28$ & 47.40 & 258.45 \\
\hline 1991 & $72,329.11$ & 277.70 & 730.72 & $2,733.44$ & 10.49 & 263.14 \\
\hline 1992 & $71,415.29$ & 266.41 & 700.95 & $(5,137.70)$ & $(19.17)$ & 263.11 \\
\hline 1993 & $76,612.56$ & 279.65 & 730.39 & $2,860.43$ & 10.44 & 261.18 \\
\hline 1994 & $81,122.19$ & 295.82 & 751.04 & $2,275.27$ & 8.30 & 253.89 \\
\hline 1995 & $84,147.17$ & 299.36 & 756.24 & (438.94) & $(1.56)$ & 252.62 \\
\hline 1996 & $93,820.95$ & 320.02 & 819.43 & $4,919.41$ & 16.78 & 256.06 \\
\hline 1997 & $101,125.62$ & 335.86 & 859.32 & $2,533.40$ & 8.41 & 255.85 \\
\hline 1998 & $104,417.36$ & 340.40 & 864.26 & $(1,840.13)$ & $(6.00)$ & 253.90 \\
\hline 1999 & $108,144.00$ & 348.71 & 872.85 & $(1,297.78)$ & $(4.18)$ & 250.31 \\
\hline 2000 & $129,934.69$ & 402.09 & $1,023.83$ & $15,745.71$ & 48.73 & 254.63 \\
\hline 2001 & $144,611.94$ & 434.89 & $1,113.47$ & $6,588.31$ & 19.81 & 256.03 \\
\hline 2002 & $148,239.15$ & 449.85 & $1,116.38$ & $(1,297.24)$ & $(3.94)$ & 248.17 \\
\hline Total for Period & & & & $82,404.71$ & & \\
\hline $\begin{array}{l}\text { Average annual } \\
\text { for Period }\end{array}$ & $4,632.47$ & & & $2,575.15$ & 10.72 & 267.32 \\
\hline \multicolumn{7}{|c|}{ Sources: Results from author's computations based on data from the following databases: } \\
\hline \multicolumn{7}{|c|}{ 1. IMF, Direction of Trade Statistics Yearbook (on-line version). } \\
\hline \multicolumn{7}{|c|}{ 2. IMF, Global Development Finance, 2003 (on-line version). } \\
\hline \multicolumn{7}{|c|}{ 3. IMF, International Financial Statistics (on-line version). } \\
\hline \multicolumn{7}{|c|}{ 4. World Bank, World Development Indicators, 2003 (on-line version). } \\
\hline
\end{tabular}




\begin{tabular}{|c|c|c|c|}
\hline \multicolumn{4}{|c|}{$\begin{array}{l}\text { Table 4: External Debt And Net External Assets (1971 - 2002) } \\
\text { (Millions of US Dollars) }\end{array}$} \\
\hline Year & External Debt & $\begin{array}{c}\text { Net external assets based on Capital flight } \\
\text { adjusted for inflation (1995 US \$) }\end{array}$ & $\begin{array}{l}\text { Net external assets based on capital } \\
\text { flight adjusted for interest earnings }\end{array}$ \\
\hline 1971 & 960 & 1,064 & -342 \\
\hline 1975 & 1,687 & 18,247 & 7,109 \\
\hline 1980 & 8,921 & 31,364 & 18,012 \\
\hline 1981 & 11,421 & 16,257 & 8,738 \\
\hline 1985 & 18,643 & 5,733 & 6,711 \\
\hline 1990 & 33,439 & 21,322 & 31,464 \\
\hline 1991 & 33,527 & 23,967 & 38,802 \\
\hline 1992 & 29,019 & 23,338 & 42,397 \\
\hline 1993 & 30,736 & 24,481 & 45,877 \\
\hline 1994 & 33,092 & 24,400 & 48,030 \\
\hline 1995 & 34,093 & 22,961 & 50,055 \\
\hline 1996 & 31,407 & 30,566 & 62,414 \\
\hline 1997 & 28,455 & 36,051 & 72,671 \\
\hline 1998 & 30,294 & 32,371 & 74,123 \\
\hline 1999 & 29,128 & 32,240 & 79,016 \\
\hline 2000 & 31,355 & 45,759 & 98,580 \\
\hline 2001 & 31,042 & 52,660 & 113,570 \\
\hline 2002 & 30,476 & 51,929 & 117,763 \\
\hline Per Capita & & & 887 \\
\hline \multicolumn{4}{|c|}{ Source: Results from author's computations based on data from the following databases: } \\
\hline \multicolumn{4}{|c|}{ 1. IMF, Direction of Trade Statistics Yearbook (on-line version). } \\
\hline \multicolumn{4}{|c|}{ 2. IMF, Global Development Finance, 2003 (on-line version). } \\
\hline \multicolumn{4}{|c|}{ 3. IMF, International Financial Statistics (on-line version). } \\
\hline \multicolumn{4}{|c|}{ 4. World Bank, World Development Indicators, 2003 (on-line version). } \\
\hline
\end{tabular}

Table 5: Ordinary Least Square Estimates

\begin{tabular}{|c|l|l|c|c|}
\hline Variable & Coefficient & Std. Error & T-Statistic & Probability \\
\hline C & $3.90 \mathrm{E}+09$ & $1.71 \mathrm{E}+09$ & 2.272743 & 0.0304 \\
X2 & 83374724 & 7410495 & 11.25090 & 0.0000 \\
\hline R-squared & 0.808408 & Mean dependent variable & $1.96 \mathrm{E}+10$ \\
Adjusted R-squared & 0.802022 & S.D. dependent variable & $1.27 \mathrm{E}+10$ \\
S.E. of regression & $5.65 \mathrm{E}+0.9$ & Akaike info criterion & 47.80662 \\
Sum of squared residual & $9.56 \mathrm{E}+20$ & Schwarz criterion & 47.89823 \\
Log likelihood & -762.9060 & F-statistic & 126.5827 \\
Durbin-Watson & 0.165281 & Probability (F-statistic) & 0.000000 \\
\hline
\end{tabular}

Independent variable: Annual External Debt Stock

Dependent variable: Cumulative capital flight with interest earnings (Percentage of GDP)

Sample: 1971 - 2002 (Included observations: 32)

\section{BIBLIOGRAPHY}

1. Ajayi, Ibi S. An Economic Analysis of Capital Flight from Nigeria, World Bank, Policy research working papers, No. WPS 993, October 1992.

2. Ajayi, Ibi S. An Analysis of External Debt and Capital Flight in the Severely Indebted Low Income Countries in sub-Saharan Africa, Working paper for the International Monetary Fund, No. WP/97/68, 1997.

3. Boyes, James K., and Ndikumana, Leonce. Is Africa a Net Creditor? New Estimates of Capital Flight from Severely Indebted sub-Saharan African Countries 1970-1996, The Journal of Development Studies, Vol. 38, Iss. 2, 2001.

4. Claessens, Sting and David Naude, Recent Estimates of Capital Flight, World Bank Working Paper, No. 1186, 1993.

5. Cuddington, J. T., Capital Flight: Estimates, Issues and Explanations, Princeton Studies in International Finance, No. 58, Princeton, N.J.: Princeton University, 1986. 
6. Cumby R., and Levich, R.M., On the Definition and Magnitude of Recent Capital Flight, Washington, D.C.: Institute for International Economics, 1987.

7. Daniels, Joseph P. and VanHoose, David D., International Monetary and Financial Economics, (Second Edition) South-Western Publishing, 2002.

8. Dooley, Michael P., Capital Flight: A Response to Differential Financial Risks, IMF Staff Papers Vol. 35 , No. 3. Washington, D.C.: International Monetary Fund, 1988, pp. 422-436.

9. Erbe, Suzanne, The Flight of Capital from Developing Countries, Intereconomics, November/December 1980, 268-275.

10. Financial Times, Abacha's Loot, January 28, 2000.

11. Hermes, Niels and Lensinsk, Robert, The Magnitude and Determinants of Capital Flight: The Case of Six subSaharan African Countries, De Economist Vol. 140, No 4, 1992.

12. International Monetary Fund, Balance of Payment Statistics Yearbook, Washington, D.C.: 2003.

13. International Monetary Fund, Directory of Trade Statistics Yearbook, Washington, D.C.: 2003.

14. International Monetary Fund, Global Development Finance, Washington, D.C.: 2003.

15. International Monetary Fund, (Managing Director) Transcript prepared in advance of the Conference of African Heads of State in Libreville, Gabon, January 18-19, 2000.

16. Lacey, Marc. Africa: Nigeria Leader Makes Plea for Stolen Money. New York Times, June 14, 2002, Section A, Column 4, Page 8.

17. Lessard Donald R., and Williamson, John. Capital Flight and Third World. Washington, D.C.: Institute for International Economics, 1987.

18. Morgan Guaranty Trust Company, Capital Flight and Third World Debt, World Financial Markets, Mar. 1986.

19. New Economics Foundation. Drops of Oil in a Sea of Poverty (The Case of New Debt Deal for Nigeria). Jubilee Plus report presented at Commonwealth Heads of Government Meeting, Brisbane, Australia. September 2001.

20. Ogbe, N.E. Evaluation of Nigeria's Debt Relief Experience (1985-1990), OECD Technical Paper No. 55, March 1992.

21. Omotoye, Richard O., et al. Sub-Saharan Africa's Debt Crisis: Analysis and Forecast Based on Nigeria, Business Research Yearbook: Global Business Perspectives, Volume XI, 2004

22. Onishi, Norimitsu, Going after Big Fish: New Nigerian President Trawls for Corruption, International Herald Tribune. 25 November 1999, p. 2.

23. Pastor, Manuel. Capital Flight from Latin America, World Development, 18 (1): (1-18), 1990.

24. Schneider, Benu, Measuring Capital Flight: Estimates and Interpretations, OECD Working Paper No. 194, March 2003.

25. U.S. House of Representatives, Nigeria in Transition. Congressional Hearing at the Subcommittee on Domestic and International Monetary Policy, Committee on Domestic and International Monetary Policy, Committee on Banking and Financial Services, Washington, DC. May 25, 2000.

26. United Kingdom Parliament. Joint Committee on The Draft Corruption Bill (Minutes of Evidence). Memorandum from Transparency International (UK) (DCB 18). House of Lord's Publication on the Internet; House of Commons Publications on the Internet. 13 May, 2003.

27. World Bank, World Bank Development Report, Washington, D.C.: World Bank, 1985.

28. World Bank, World Development Indicators, Washington, D.C.: 2003. 
NOTES 